\title{
Anne Peters
}

\section{Jenseits der Menschenrechte}

\author{
Die Rechtsstellung des Individuums im Völkerrecht
}

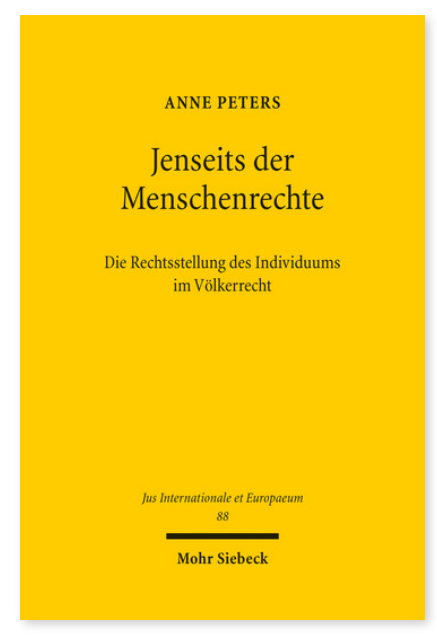

2014. XXIV, 535 Seiten. JusIntEu 88

ISBN 978-3-16-152750-0

DOI 10.1628/978-3-16-152750-0

eBook PDF $134,00 €$
Völkerrechtliche Normen sprechen Menschen zunehmend direkt an. Die Vervielfachung und Ausdifferenzierung völkerrechtsunmittelbarer materieller Rechte und Pflichten des Menschen sowie ihrer prozeduralen

Durchsetzungsmöglichkeiten haben nicht nur eine quantitative, sondern auch eine qualitative Bedeutung. Grundthese des Buches ist, dass ein Paradigmenwechsel stattgefunden hat, der den Menschen zum primären Völkerrechtssubjekt macht. Diese These wird vor dem Hintergrund der Ideengeschichte und Dogmatik der Völkerrechtspersönlichkeit des Menschen entfaltet. Vor allem wird sie aus der Praxis in zahlreichen Teilrechtsgebieten, angefangen vom Recht der internationalen Verantwortung über das Recht des bewaffneten Konflikts, das Recht der Katastrophenhilfe, das internationale Strafrecht, das internationale Umweltrecht, das Konsularrecht und das Recht des diplomatischen Schutzes, das internationale Arbeitsrecht, das Flüchtlingsrecht bis hin zum internationalen Investitionsschutzrecht abgeleitet.

Rechtsgrundlage der Völkerrechtspersönlichkeit (Völkerrechtssubjektivität) des Menschen ist Völkergewohnheitsrecht; seine Völkerrechtsfähigkeit ist ausserdem ein allgemeiner Rechtsgrundsatz und bildet einen Aspekt des Menschenrechts auf Rechtsfähigkeit. Die Herausbildung einfacher Rechte und Pflichten des Individuums (im Gegensatz zu den Menschenrechten) intensiviert die bisher schwach ausgeprägte Normenhierarchie im Völkerrecht. Der neue Völkerrechtsstatus des Menschen wird mit dem Begriff des subjektiven internationalen Rechts auf den Punkt gebracht.

Anne Peters Geboren 1964; 1994 Promotion, 2001 Habilitation Kiel; Direktorin des Max-Planck-Instituts für ausländisches öffentliches Recht und Völkerrecht in Heidelberg.

Jetzt bestellen:

https://mohrsiebeck.com/buch/jenseits-der-menschenrechte-9783161527500?no_cache=1

order@mohrsiebeck.com

Telefon: +49 (0)7071-923-17

Telefax: +49 (0)7071-51104 